\title{
UN agrees on science and development centre
}

AFTER three weeks of intense debate, member nations of the United Nations agreed late last week to set up a new policy unit to help carry out the recommendations of the Conference on Science and Technology for Development (UNCSTD) held in Vienna in August.

The new unit will be known as the Centre for Science and Technology for Development. It will be headed by an Assistant Secretary General, and is expected to involve between eight and ten new staff appointments, as well as absorbing some of the resources of the present Office of Science and Technology, which is to be abolished.

The main function of the new centre will be to service the Intergovernmental Committee which, it was agreed at Vienna, should be set up to attempt to coordinate the various programmes within the UN system concerned with applying science and technology to development, and to stimulate further activities in this direction.

A resolution calling for the setting up of the centre was finally agreed in the early hours of last Friday morning by the second committee of the UN general assembly, currently meeting in New York.

In their final form, the institutional arrangements are broadly in line with proposals made by the Group of 77 , on behalf of the developing countries, that a strict interpretation of the agreement reached in Vienna implied the creation of a new secretariat.

A number of industrialised countries, and in particular the member countries of the European Economic Community, argued strongly that no new institutional arrangements should be made - and that any new functions could be carried out by existing machinery under the Department of International Economic and Social Affairs.

In the end, however, it proved impossible to devise a compromise formula which all sides could agree upon. And the decision to establish the centre - which will report to, but not be under the direct control of, the Director General for Development and International Economic cooperation, Mr Kenneth Dadzie - was put to the vote.

The result was 97 votes in favour, none against, and 20 abstentions. Countries abstaining include members of the EEC and the countries from the eastern European bloc. Those who voted in favour included not only the developing nation members, but also the Untied States, Canada, and the Scandanavian countries.

The outcome had been held up pending the resolution of a dispute over how much direct influence UN member states should have over the way in which the United Nations Development Programme disburses the "interim fund" which the Vienna conference agreed should be set up prior to the establishment of a long-term science and technology financing system.

The Group of 77 submitted a document arguing that there should be direct involvement of the IGC - which is open to all UN member states - in the administration of the fund. The developed countries, however, and in particular the US which is likely to be a major contributor, made it clear that such a decision would prejudice their agreement to contribute.

The developing countries agreed to back down on their demands, and responsibility for its management will lie in the hands of the administrator and the governing council of the UNDP, although operating within broad policy guidelines laid down by the IGC.

(A pledging conference for the interim fund will be held early next year, and although it seems that the $\$ 250$ million target agreed in Vienna will not be reached, UN officials are optimistic that voluntary contributions totalling about $\$ 100$ million can be raised for the two years 1980-1981.)

State Department officials in Washington later expressed satisfaction with the final outcome of the second committee's discussions, claiming that a new centre headed by an assistant director general (some developing countries had argued for an under secretary general) was "just right" - and that to have accepted the Group of 77's proposals for the administration of the interim fund would have destroyed many of the gains made in Vienna.
How the US should pursue the outcome of UNCSTD is likely to be one topic discussed by a new advisory panel on science and technology for development which is being set up under the chairmanship of $\mathrm{Mr}$ Tom Pickering, assistant secretary responsible for the Bureau of Oceans, Environment and Scientific Affairs.

The panel is being established under the aegis of the bureau's advisory committee, and its first meeting is likely to be held in public. Additional topics that have been proposed for discussion include energy and development, and a forward look to the global picture in the year 2000 .

Meanwhile administration officals are still trying to salvage plans for an Institute for Scientic and Technological Cooperation (ISTC) a centrepiece to US presentations in Vienna, but for which funds have been refused by the Senate.

The House of Representatives has agreed that funds for the institute should be provided. But so far a joint House/Senate conference, which is bogged down on a number of foreign aid issues, has failed to agreenon whether funding for the institute should be provided.

One proposal currently being studied is that the ISTC should not, as initally envisaged by the administration, exist as a separate body within the US aid programme, but remain under the administration of the Agency for International Development, many of whose research programmes the ISTC w ould be taking over.
David Dickson

\section{US Congress approves $13 \%$ growth in military support for basic science}

THE US Congress last week agreed to increase military support for basic research by $13 \%$ in the fiscal year 1980 , the Senate in particular expressing its support for the Department of Defense's efforts "to overcome years of real decline in funding for this type of research".

The increase, which will bring support of basic research by DOD to about $\$ 500$ million a year, is less than the $16.7 \%$ growth initially requested by President Carter. However, in line with changing social priorities, it is considerably higher than the increases in support for basic science by other federal agencies, for example, the $8 \%$ growth for the National Institutes of Health.

Overall, Congress agreed to an $\mathbf{8 . 5 \%}$ growth in the Defense Department's spending on "research, development, testing and evaluation", from $\$ 12.3$ billion to $\$ 13.4$ billion. Much of this increase will be allocated to support of the "technology base", which includes research on high energy systems, such as lasers and particle beams, as well as high speed integrated circuits.

In particular, support for R,D,T and E activities within the defense agencies responsible, for example, for the Defense Advanced Research Projects Agency (DARPA) - will grow by $8 \%$.

University research workers are likely to be a beneficiary of the increased spending. Although last year Congress refused to establish a proposed "defense science and engineering programme" aimed at increasing the effectiveness of relationships between the DOD and university scientists, it has given encouragement to the department's efforts in this direction.

The Senate in particular has given support to an increased emphasis on basic research within the $R$ and $D$ budget. Although the House of Representatives had made several cuts in the President's budget request, many of these were restored by the Senate, and subsequently accepted at a conference between the two houses. 